\title{
Reading the Myth of American Freedom: The U.S. Immigration Video
}

\author{
Camille Reyes 1 \\ Department of Communication, Trinity University, San Antonio, Texas, United States
}

\begin{abstract}
The U.S. Citizenship and Immigration Services (USCIS) department offers immigrants wishing to naturalize, or become citizens, a package of study aids for the citizenship test, including a video. This essay argues that the video is much more than a study aid; it furthers the myth of American freedom, a myth that effectively erases the struggles of marginalized groups. Situated within critical cultural studies and semiotics, the essay describes the content of the video and interprets the myth. The deployment of diversity is considered, along with implications for immigrants who intersect with some of the marginalized or absent groups.
\end{abstract}

Keywords: citizenship, cultural studies, immigration, marginalization, semiotics.

\section{Introduction}

Perhaps nothing is more emblematic of the "good life" in the American imagination as the immigrant experience. People both within and outside of the United States identify with the notion that America is the "land of opportunity," and importantly for immigrants2, a "melting pot" of ethnicities and perspectives. (Although, as Berray (2019) asserted, such food metaphors are deeply problematic for their coercive, homogenizing effects.) Alongside these dominant narratives, however, exist material conditions challenging the vision of equal access to the American experiment in the pursuit of happiness. These conditions seem especially fraught for immigrants trying to attain "the good life" both for themselves and often for families "back home." Nationalist rancor, hostile political environments, income inequality, language barriers, and digital divides are several of the obstacles prevalent in the contemporary immigrant experience.

Immigrants, as subjects of media, become politically charged sites of contestation. As Benson (2013) detailed, U.S. (and French) media employ myriad frames, or perspectives, on the "issue" of immigration from immigrant-as-victim to hero to threat. These frames have consistently helped to make immigration a perennial hot-button issue in American politics. Although the Trump administration has overshadowed many controversies of the Obama administration related to immigration, President Obama was dubbed the "Deporter in Chief" - a reference to the then recordbreaking number of undocumented immigrants deported from the United States during his tenure.

In 2018, even the definition of "citizen" was called into question as the Trump administration reportedly revoked U.S. passports at the Texas-Mexico border due to doubts about the legitimacy of birth certificates (Sieff, 2018). The following summer, the border patrol faced harsh publicity as a young American was detained for 23 days "in conditions that made him so desperate he almost opted to self-deport" before his release (Manuel, 2019). This news, combined with the separation of children from their parents by Customs and Border Protection (CBP) at the

1 Correspondent e-mail: creyes3@trinity.edu

2 Despite its contested political use in globalization studies, the term 'immigrant' is used throughout the text in order to be consistent with the government's usage. 
U.S./Mexico border in 2018 and 2019, as well as other high profile policy shifts and ugly rhetoric about immigrants from President Trump prompts questions about the government's public relations efforts aimed at those people it ostensibly wants to join the union, in other words prospective citizens willing and able to pay significant amounts of money and time to clear the hurdles of 'naturalization'.

Despite the material and political chaos of migration, especially for Latinx immigrants, there are still hundreds of thousands of people who wish to undertake the long process of becoming naturalized U.S. citizens. How is this group communicated to given the frequently violent rhetoric and policies against immigration coming from the U.S. government? What sort of notion of freedom is being conveyed to prospective citizens during these turbulent times? This essay will examine such research questions by deconstructing one piece of the strategic communication produced for the U.S. government, namely a video for prospective citizens preparing for the citizenship test.

Although the simple imagery and language used in the video may belie it, freedom in this example is a complex political, social, and economic expression tied to shifting notions of American democracy. Cultural critics of the contemporary American landscape argue that the United States is no longer a democracy (Chomsky, 2013). Free market values (heavily and not so invisibly aided by favorable State policies) assault egalitarian notions of justice, reducing freedom to voting and shopping. Giroux (2008) asserted, "There is no language here for recognizing antidemocratic forms of power, developing nonmarket values, or fighting against substantive injustices in a society founded on deep inequalities, particularly those based on race and class" (p. 66). Perhaps in decoding the myths of the State--in revealing the erasure of inequalities--one finds language that at least gestures towards justice.

These inequalities envelope migrant groups, too, as hundreds of thousands of prospective citizens lack the privileges of money, knowledge, time, connections - in short power - to gain the coveted status of "citizen." Multiple studies have shown that the label placed upon immigrants matters (Anguiano, 2015; Chavez, 2013; Mason, 2019; Meier, 2019; Quinsaat, 2014). For example, in an experimental study, Hoops and Braitman (2018) found: "Participants who received a narrative prompt with the term 'illegal immigrant' evaluated the character's situation with internal attribution, and thus deserving of any negative outcomes, such as racial profiling, deportation, and separation from one's family" (p. 2).

Across the world, citizenship is generally established in one of two primary ways: where one is born (e.g. U.S., Canada, much of Latin America), or the nationality of one's parents (e.g. U.K., France, Netherlands, parts of Germany). Many nations, including the U.S., require a test of civics and history, as a part of the process of naturalization. Along with the test, the U.S. government provides a number of study aids online, including the subject of this essay, a professionally produced, theatrical video.

This video, produced in 2007, has yet to be a subject of controversy, but the test to which it corresponds certainly has. In 2006, the U.S. Citizenship and Immigration Services (USCIS) introduced a new citizenship test with "stiff resistance from immigrant groups" (Etzioni, 2007, p. 354). According to Etzioni (2007), the new test, it was feared, would make it more difficult for many immigrants to gain citizenship, especially those people with limited English language skills. "Citizenship tests [...] are [...] very often used as a tool to control the level and composition of immigration" (Etzioni, 2007, p. 353). In 2019, the Trump administration announced plans to edit the citizenship exam again (Alvarez \& Sands, 2019). According to CNN, "The Trump administration has sought to crack down on legal and illegal immigration. And while it's unclear what exactly the administration intends to change on the test, it appears to fall in line with the President's agenda" (Alvarez \& Sands, 2019). 
Such attempts at control by governments prompt many questions (and protests) as to how and why some groups are more or less subjugated. To some extent then, the USCIS mediates the American immigrant experience of citizenship-- narrowly defined as access to certain rights and responsibilities bounded by nationality. The question of how the video mediates this experiencewhat amounts to the myth of American freedom-will be addressed shortly.

First though, it is important to point out that the U.S. is not the only country to produce socalled acculturation videos, media produced by/for the State meant to address immigrants in some fashion. Germany, with its controversial, comparatively liberal contemporary immigration policies, offers a number of short ten-minute videos in five languages (Federal Office for Migration and Refugees - Germany, 2019). Greece, with one of the strictest immigration policies in Europe (Human Rights Watch, 2019) also offers short videos and a comic book in different languages, all specifically pointed toward refugees (Helenic Republic Ministry of Interior, 2019; Kusumastuti, 2019). The French Office of Immigration and Integration (2019) perhaps expects fluency for its potential immigrants as it offers a French-language-only website. The Netherlands encourages prospective citizens to view a feature-length film entitled Naar Nederland (Anonymous, 2009).

These efforts, while out of scope here, do provide insights as to the scale of such strategic media. For example, in contrast to the U.S. video, the Dutch film is more overtly engaged in a project of socialization versus the American study aid, although both texts are arguably tools of public relations for their respective nations. This claim about the Dutch film is bolstered by the nature of the surrounding citizenship test that asks questions such as: "What should one do with the front garden for it to be accepted as Dutch? What should one do when one has a newborn baby?" (Brown, 2012, p. 25). The U.S. citizenship test, by contrast, asks how many U.S. Senators there are.

Of course, such governmental communication for and/or about immigrants has a long history. One particular, past campaign to assimilate Hungarians and Cuban refugees during the Eisenhower administration illustrates the nuances and policy goals embedded in such strategic communication. As Bradford (2019) highlighted, "These discourses sought to 'sell' Hungarians and Cubans to an immigration-averse public by emphasizing their affinity with American values, especially their Christian beliefs and dedication to hard work and family, even as they deemphasized the escapees' Catholic identity" (p. 43). Such value-driven work is abundant throughout The Promise.

The work of strategic communication in ethnic museums parallels the challenges of video production examined here. Practitioners in the museum setting attempt to resist homogenous messaging while honoring the importance of unity and the perils of erasure. In her study of public relations practice within ethnic museums, Johnson (2020) found one tactic--comparing the experience of marginalized immigrant identities today with those of the once-marginalized, but now successful immigrants of the past-- to be a highly effective, inspirational narrative of overcoming. Thus, media directed at immigrants has demonstrated potential to be something progressive. However, as this essay will argue, the USCIS video falls short.

\section{Theory}

The U.S. video, interpreted here as nationalist propaganda, performs a great deal of mythmaking to be analyzed at length using semiotics. Starting from Saussure's use of 'sign', 'signifier', and 'signified' we see how the signifier of the English word 'promise' (deployed frequently in the video) delivers the signified of a pact of some kind, resulting in the sign as the union of the letter pattern and the associated idea. This process, Saussure stressed, is arbitrary - a fact illustrated by 
the multitude of languages spoken on earth (Howells \& Negreiros, 2012). Barthes (1972) built upon this system of signs to interpret deeper, ideological, or non-arbitrary, meaning in texts of all kinds including popular culture. This so-called second order of signs (Barthes, 1972) becomes the workshop of mythologist, where the signs of language synthesize to a greater level of meaning. For example, the sign for a dog is transformed or embellished in many cultures to become a sign for "fidelity" (Howells \& Negreiros, 2012, p. 119). Or to take an example from the video at hand, the sign for a flag is filled to become a sign for power when the Stars and Stripes are emblazoned on the side of a rocket to the moon.

This essay uses a semiotic lens within a cultural studies context-where power has long been viewed as contingent and relational by the likes of Hall, McRobbie, Das Gupta and others considered here. Communicative, strategic power-- situated in the current moment of neoliberal nation branding - flows in both symbolic and constitutive ways. This means that something like the immigration video studied here is far more than a bureaucratic media object. Aronczyk (2019) wrote, "researchers are continually surprised by the degree of attachment people feel to the stories, symbols, and values that make up placebased brands" (p. 442).

Finally, at a meta level, academic scholarship should be subject to some of the same critiques leveled against UCIS here. For the erasure of certain identities in an effort to promote strategic cultural values is a risk known to researchers, too. In this vein, Asante (2019) claimed, "Citational patterns that continually legitimize the racialized and gendered foundations of a White and masculine-dominated field concomitantly disavow the accounts of people of color, queers and third world knowledge(s)" (p. 486). The American focus of this essay could be read as somewhat hypocritical to which the author reveals that as an American citizen, she must write what she knows, and she has purposefully referenced scholarship from a diverse, international group of scholars.

\section{Method}

With the theoretical lenses of semiotics and cultural studies established, we now turn to the application of textual, interpretative methods comprising the close reading presented here. First, research questions related to the video were established: 1. How does the U.S. government communicate to prospective citizens in the context of the current, divisive rhetoric about immigration worldwide? What strategies are deployed to shape meaning? 2. How is the notion of freedom - so central to the idea of the United States - conveyed? Building from these questions, the researcher studied the many current discourses related to immigration, some of which were signaled in the introduction. Finally, the author deconstructed the video using semiotics and analytic induction. Patterns emerged through repeated viewings which formed the categories of interrogation. This deconstruction was performed at the micro, word/image level and at the macro, meaning level, where meaning is polysemic and therefore open to interpretation.

As we transition to the video analysis, the contents or signifiers will be described in chronological order, followed by a reading of the myth in each section. This essay argues that the U.S. video is much more than a study aid; it furthers the myth of American freedom, a myth that, in the video, erases the struggles of minority and marginalized groups.

The 12-minute U.S. video is available streaming online with English, Spanish and Chinese captions; it was produced by the National Constitution Center in Philadelphia for the U.S. in 2007. The video is presented as part of a larger package of study aids on the web site including a simulation of the citizenship test itself. In the description and analysis that follows, I divide the video into chapters of my own naming and length for ease of presentation. 


\section{Analysis}

\section{Will This Be on the Exam?}

The video, entitled A Promise of Freedom: An Introduction to U.S. History and Civics for Immigrants, (referred to henceforth as "Promise") begins with an audio recording played over a basic title card. The recording sounds as if a naturalization ceremony in court is taking place. According to the voice in the courtroom, "56 nationalities" were represented. At 0:15, a montage of different, multi-cultural faces appears, starting with a young woman, perhaps of African descent, wearing a head wrap. In the supposed voices of the nationalities spoken, some countries represented in the courtroom are named: "Ecuador. Somalia. France." Then, a new voice over is introduced, that of a professional actor with a dramatic voice similar to that heard in movie previews. The voice asks, "What makes us Americans? What makes people from all over the world want to become U.S. citizens?" The Promise offers some answers, starting with the U.S. Constitution. In what will become a common refrain both visually (through the use of a cropped image of the text on what appears to be an original document) and aurally, the viewer is exposed to the phrase, "We the People" before the next section begins.

The choice of starting with audio from a naturalization ceremony is, in a way, starting at the end, with the reward of citizenship gained, at least in part, by a good performance on the citizenship exam. This invites the immigrant viewer to imagine success and perhaps encourages them to pay attention to what follows, a study aid, and at its most basic level of semiotics: a collection of sentences uttered, still images set into motion with music. Yet all of these component parts calcify into myth. "We must here recall that the materials of mythical speech (the language itself, photography, painting, posters, rituals, objects, etc.), however different at the start, are reduced to a pure signifying function as soon as they are caught by myth" (Barthes, 1972, p. 114). For Barthes (1972), myth is very much connected to ideology, and therefore hinges on the idea of something seeming natural. How ironic then that the very process of gaining citizenship in much of the world is called naturalization. In this case, the myth delivered is that of the American dream to be explored throughout (Bittman \& Russell, 2016; Kenna, \& Russell, 2018; Moore, 2018).

At this introductory phase of the film, the U.S. Constitution is first used to signify "American," a word that from the title of the film ("The Promise of Freedom") alone, likely connotes freedom. Notice the use of the word promise in relation to freedom. A "paradigmatic chain" (Saussure, 1906/1974) might include the following: hope, promise, pledge, vow, guarantee. Following Chandler (2017), paradigmatic (or previously understood groups of signifiers) analysis looks for similarities and differences in a given text. For the title and frequent refrain of the video, the producers/mythologists choose the word 'promise' in relation to freedom from a wide range of choices. Hope is similar, yet it connotes a less likely outcome. A pledge is more individual in nature, and often thought of as a person making an allegiance to some organization (e.g. the pledge of allegiance to the flag). A vow has religious connotations which if used might put freedom in connection with zealotry (Andrews, 2019; Cowgill \& Waring, 2017). Thus, the word promise is chosen in relation to freedom in the title to serve as an umbrella action for the film. For now, the Constitution is further imbued with a vaguely populist notion: "We the People."

\section{Brave New World}

At 1:18, the narrator informs the viewer that, "Although Native Americans had lived here for centuries," the early European settlers came to the "new world" for "many of the same reasons 
people come here today." (National Constitution Center, 2007). The Promise did not specify what these reasons might have included, now or then. In roughly the following minute, the Promise sums up the primary problem with British rule over the colonists: taxation without consent.

There is neither a mention of other European settlers, nor of the atrocities committed against the Native Americans. Discovery is emphasized. Did the colonists come to America to flee religious persecution, (a myth resurrected annually on Thanksgiving Day)? Were the settlers motivated by monetary gain? Whatever the reasons, the ambiguity is connected explicitly by the narration to immigrants today. This moment is activating a sub-section of the American dream myth, one that relies heavily on tropes theorized by Hall (2003) in a different context.

Hall (2003) painted a sketch of three tropes: the slave-figure, the native, and the clown (p. 92). The tropes, Hall (2003) explained, are always juxtaposed with what is seemingly natural in the world, and contain dichotomies such as simple/savage or innocent/sexual. Hall (2003) wrote, "Both are aspects - the good and the bad sides - of primitivism. In these images, primitivism is defined by the fixed proximity of such people to Nature" (p. 92). The slave-figure will appear later in the video; the clown is absent - a missing trope that also serves a function to be explained momentarily. In this section of the video, the figure of the native is immediately erased by the assumed superiority of the European settlers in the creation of a new world, despite people closer to nature having lived there long before. For Native Americans, the land did not need to be discovered or renamed. This new world was better by virtue of being new; the implication holds the dichotomy-- that the civilized had arrived to tame the savages. The convenient omission of the Native American subjectivity turns the land into an object divorced from "its historical genesis"its humanity, and creates "the fiction of a place [...] (une place proper)" (de Certeau, 1984, p. 44).

To understand this more deeply using Barthes (1972), here the video uses the "privation of history" figure where "[m]yth deprives the object of which it speaks of all history" (p. 151). Here the brutality of colonization - carried out by immigrants no less - is erased in the ideology of the new world - of nascent, pure, innocent discovery in contrast with the coded savagery of the native.

Here the aforementioned clown trope is missing perhaps because of the intended audience. Barthes (1972), when speaking of the power of the figure of identification in myth, explains that the clown is used only in "emergencies" when the Other cannot be assimilated or identified as part of the desired class structure (p. 152). At such times, the clown or similar exotic figure is used to reduce the threat of the Other (Barthes, 1972) As an acculturation video, assimilation, or bringing the immigrant Other into the fold, is precisely the strategic point of the Other. Turning the Native American into a cartoon, as so often seen in both contemporaneous (e.g. the Cleveland Indians baseball mascot) and historical artifacts, is not an option here if the promise of the myth is to be fulfilled. After all, it would not do to have the future citizen identifying with the Other-better to include him with the happy new world family. As Barthes (1977) said, in advertising all signs are filled to the brim, "formed with a view to the optimum reading: the advertising image is frank, or at least emphatic" (p. 33). The video is a promotional tool for the nation. Thus, the sign of the new world is filled completely by freedom, it has no room for clowns; this myth of freedom is all consuming - it is the viewer, the soon-to-be-citizen.

\section{The Declaration of Independence \& 1776}

Just over two minutes into the video, the Promise quotes parts of the Declaration of Independence: "all men are created equal [...]; life, liberty and the pursuit of happiness." The narrator continues, "Over time, the idea of equal rights included all people in the United States" (National Constitution Center, 2007). Over images from American revolutionary history- 
paintings of the Founding Fathers, documents, etc., the viewer learns that eight of the signers of the historic document were immigrants (National Constitution Center, 2007).

The juxtaposition of equal rights for all and the mention of the immigrants who signed the Declaration of Independence are purposeful. The qualifier "over time" to describe the inclusion of all people is, to put it mildly, not accurate. Undocumented immigrants, LGBT people, women, and many other marginalized groups do not enjoy equal rights in the United States. The phrase "over time" is used at the beginning of the statement, de-emphasizing it further. The proximity of the eight signers, i.e. the inclusion of immigrants from the birth of the nation, to the false assertion of universal human rights further diminishes the important qualifier "over time." The analysis will return to those left out of equality at several points.

\section{The American Revolution}

At 3:26, the viewer confronts war to the sounds of furtive strings, dramatic horns and rumbling drums-- all scored to illustrations with fire burning over them. After the epic, bloody struggle, "a young country was born," but the states were not yet unified; this would take months of "intense debate" leading to the U.S. Constitution (National Constitution Center, 2007). Amidst numerous close-ups on the cursive script from the Constitution, the Promise delivers a civics lesson explaining the three branches of government and the supposed locus of power-the American people. The narrator intones, "The power and responsibility for freedom, belong to us - the citizens of the United States--We the People" (National Constitution Center, 2007), as images of the Declaration of Independence flash again across the screen.

The American Revolution is one of only two wars covered in this "introduction to U.S. history," the other being the Civil War (National Constitution Center, 2007). Although immigrants to the U.S. are far from a monolithic category, it is safe to claim that many come from countries perhaps recently embroiled in revolutions of their own. The originality of the American Revolution is stressed; freedom is with the people, not the government and this power is carefully considered and divided, a responsibility of great importance to citizens. This foundational war and the emergent Constitution now join together to repeat the idea of freedom, along with the repetition of the phrase, "We the People." According to Barthes (1972), "This repetition of the concept through different forms is precious to the mythologist, it allows him to decipher the myth: it is the insistence of a kind of behavior which reveals its intention" (p. 120). In the video, the intention is to connect freedom to U.S. citizenship, to further the myth of America, 'the land of the free, the home of the brave.'

To the sounds of a bell tolling at 6:48, the Promise explains that the Constitution had changed through the years due to many amendments, the first ten called the Bill of Rights. These rights are referred to as "very basic," and the following rights are summarized (in order): freedom of religion, freedom of speech, right to a fair trial, right to bear arms, "and other important liberties" (National Constitution Center, 2007).

It is difficult to discern why the producers chose to highlight some of the rights over others. Certainly choices must be made for the sake of brevity, however it would seem like the Fourth Amendment pertaining to unlawful search and seizure by the government might be particularly relevant to immigrants coming from Authoritarian regimes, for example. That said, the important aspect of this section is the idea that the Constitution, constructed as the foundational document of American freedom, is amendable. 


\section{The People Protected-Eventually}

This section of the video pertaining to the people protected by the highest law of the land begins with images of men of State, transitioning into a black and white image of a woman with child in old-fashioned clothing, followed by the image of a Native American man as the voice-over read, "Many groups of people were denied certain freedoms in the past..." (National Constitution Center, 2007). As a photo of Frederick Douglass appeared, the narrator continued, "but have gained equality through amendments through the U.S. Constitution" (National Constitution Center, 2007).

At $7: 41$, there is a transition to the image of another black man, a soldier from the Civil War era. As the slavery discussion begins, the viewer learns, "It took 75 years and a Civil War to end slavery. And it was another 100 years until laws were passed to make it illegal to discriminate against people based on race, color, religion, sex, or national origin" (National Constitution Center, 2007). During the latter narration, the images change to a group of mixed race people on the street with buses nearby and a sign in the background that said, "White Waiting Room," followed by a picture of Dr. Martin Luther King, Jr.

In the eighth minute, the video highlights the 1965 Voting Rights Act, explaining that it allowed every citizen to vote, and at the same time removed "unfair restrictions on immigration" (National Constitution Center, 2007). The narrative, timed with pictures of the Washington Monument, Lyndon Baines Johnson signing legislation, and a montage of immigrants photographed in black and white, says, "This [Voting Rights Act] allowed many legal immigrants from all over the world to come to America and make this country their home" (National Constitution Center, 2007).

The video uses the figure of "inoculation" (Barthes, 1972, p. 150) in its quick treatment of the Civil War and the Civil Rights movement - not even named here, but referenced in the laws following the 100-year gap between the two periods. "One immunizes the contents of the collective imagination by means of a small inoculation of acknowledged evil; one thus protects it against the risk of a generalized subversion" (Barthes, 1972, p. 150). Here, the mythologists admit that it took a long time for equality in the United States. This small, abstract mea culpa (who exactly was denying those rights?) protects the nation from 'generalized subversion' lest these new citizens get any ideas that the promise of freedom is not yet fulfilled for everyone.

In addition, the figure of 'privation of history' is employed again when these pictured men of color who made history go unnamed. Would the average immigrant recognize Frederick Douglass for example? Without such recognition, the signifier (Douglass) is not able to take on the identification of the signified man and his place in history, much less the second-order signified, the myth of freedom. Far from a mistake, I argue this particular abstraction, even if not intended, is purposeful. Barthes (1972) footnotes Marx from The German Ideology, 'We must pay attention to this history, since ideology boils down to either an erroneous conception of this history, or to $a$ complete abstraction from it' (p. 151). The image of Douglas without name and zero explanation is such an abstraction and sits within the larger narrative that voting fulfils the promise of freedom. The video implies that the moment African-Americans legally achieve the franchise, all the ills of slavery and later segregation and prejudice are wiped clean. This statement is absurd when stripped from the sweeping images, stirring music, and assertive voice over, but of course, in regular viewing no such isolation occurs, preserving a sense of progress without (much) history.

\section{A Nation of Dreamers}

Next, the editors assemble a montage filled with the following images: presumably immigrant-filled classrooms old and new with happy children, the Stature of Liberty, Jews at 
prayer, a Chinese family sitting for a portrait, men walking next to an early airplane, workers in a factory, a boat with people sitting on a lake shore. Over this cascade of images, all but one (of a classroom) is in black and white, the narration asserts that Americans "imagine, invent and live our lives as we choose" (National Constitution Center, 2007). The script continues, "We've been free to dream (juxtaposed with a black and white photo of President Kennedy) and make those dreams become real" (National Constitution Center, 2007). The last portion of the latter statement was timed with a brief movie clip of a rocket with "USA" emblazoned on its side.

With swelling strings and patriotic horns in a major key, another montage, a mixture of black and white and color photography, begins as follows: the U.S. Capitol building, the Statue of Liberty, a Latino holding a child, a Black person getting a degree with a White woman and a White man flanking. During the montage, the Promise script asserts, "The Constitution protects our many freedoms. It also allows each person to decide how to use these freedoms" (National Constitution Center, 2007). This is followed by more images of presumably multi-ethnic people.

Here the myth of freedom comes dangerously close to revealing itself in the language of dreams. This is not to suggest, however, that a myth is a lie. On the contrary, as Barthes (1972) explained, "[M]yth is neither a lie nor a confession: it is an inflexion" (p. 129). Here, the embellishment to the language of the video adds another layer to the myth of freedom already in progress. Now the viewer confronts the moment of American possibility: with freedom for all, anyone can do anything, or so the promise would suggest.

In the dreamer chapter, the myth is colored with the idea of American individualism, and not just any individuals, but individual immigrants. To be fair, many of the images in this section show groups of immigrants (Jews at prayer, a Chinese family), but the action in the images is nonthreatening. There are no images, for example, of Muslims protesting in the streets. The only action outside of the home depicted is of workers in a factory, an image very much in line with notions of capital given the larger context of the United States. It is as if the image of the workers suggests that you too could become a part of larger dream, the dream of the capitalist. The dream section culminates with visual references to Kennedy's space program, produced as a response to the Cold War, a long period of American history conveniently unmentioned in any denotative sense.

\section{Speaking Directly to Immigrants}

Near the end of the video, the narrator of the Promise (National Constitution Center, 2007) delivers the following direct address:

Whether you are a new immigrant or ready to apply for citizenship, freedoms and rights come with important responsibilities: make a commitment to be part of your community; get to know and help your neighbors; discuss the issues that affect your community; learn English; learn about U.S. history and government; and respect the law. If you become a U.S. citizen, serve on a jury if you are called to do so... and vote.

The last two words of the direct address are almost a stage whisper. The narrator asserts, "The right to vote allows each citizen to help the nation remain strong and grow," over an image of a polling place sign with a handicap symbol on it (National Constitution Center, 2007). As pictures of multi-ethnic faces fill the screen, the Promise constructs the vote as a duty and the (only) mechanism for having a voice in government and for change. 
At 10:27, the video introduces a few rhetorical questions about nationhood tying back to early Colonial history and the Constitution. Color images of presumably immigrants transition to images of figures and scenes from revolutionary history. Then, the narration slows, reaching a dramatic climax: "and it [the Constitution] begins with three words: We the People" (National Constitution Center, 2007). The text of the preamble of the Constitution appears with a crescendo of patriotic music. The scene then returns to the audio of the courtroom referenced at the beginning of the video. The voice of a judge says, "The time has come to take the oath" (National Constitution Center, 2007).

The screen divides into a grid of multi-ethnic faces, close-ups. The music stops as the pictures transition within the squares. The narrator of the Promise (National Constitution Center, 2007) poses a final question: "Now it is your decision... What will you do with freedom?" The end title card then appears with the judge voiceover returning, punctuated with applause, saying, "Our country now is better off than it was a few minutes ago" (National Constitution Center, 2007).

The direct address that begins this final section of the video marks a jarring shift in tone. Up until this point, the video invites the immigrant viewer to absorb "the" history of the U.S. and imagine a place in this land of freedom, a place to shape the history of the nation going forward. Here, the point of view shifts; the immigrant is no longer expected to imagine or dream as in the previous chapter; the immigrant receives a list of instructions. The first three of the eight directives concern community: Immigrants are to be participatory members of their communities. Such participation, it is implied, requires learning English. The call to learn about history and civics is an explicit statement of the ostensible purpose of the video, as a study aid for the citizenship test. The narrator demands respect for the law; the command belies the assumption of an audience of "unruly immigrants" (Das Gupta, 2006). Finally, the list ends with the command to serve on a jury if one is called, and of course, to vote.

The direct address returns one last time at the end of the Promise to ask a question: "What will you [the immigrant] do with freedom?" There is no question as to if the immigrant will actually attain freedom; it is a given (once the immigrant passes the citizenship test). The past struggles for freedom, even within the established nation, are reduced to bite-sized, uncomplicated morsels of "history;" current struggles are erased altogether. "Myth is constituted by the loss of the historical quality of things [....] The world enters language as a dialectical relation between activities, between human actions; it comes out of myth as a harmonious display of essences" (Barthes, 1972, p. 142). The myth of the Promise is complete.

\section{Discussion}

It could be argued that the Promise captures the diversity of the American people and their values, concepts that calcify in "the American way" similar to the way that Barthes (1977) read "Italianicity" in an advertisement, or the way that same idea creates the "feeling of Italy' at Fazoli's restaurants (Girardelli, 2004). Such a claim is likely just as valid in the Netherlands, for example, and yet for better and for worse, the Dutch film explicitly defines what it is to be Dutch. The American video, although less explicit and more mythic, does in fact also define what it means to be American; it does so not through socialization models (e.g. this is how we treat women), but rather through ideology. To be an American citizen, the video implies, is to be free, with all of the rights and responsibilities entailed. This freedom is constructed as the space to dream and realize such dreams on an equal playing field, the right to vote among many rights, and the duty to serve both country and community.

The video functions in a way that is similar to how McRobbie (2004) described the tendency of popular culture to absorb feminist thought through the appearance of having moved 
beyond the need for it, of being post-feminist. The struggles of various groups throughout American history are largely absent in the video with the exception of the aforementioned treatment of (and inoculation against) Blacks. In this sense, diversity, expressed primarily through contemporary images of immigrants, stands as evidence of post-racism and post-feminism. "McRobbie's proposition that 'postfeminism is feminism taken into account' can be amended in the contemporary American context to include 'diversity taken into account' - and, [...] an institutional kind of diversity is situated within this formulation as something belonging to history" (Banet-Weiser, 2007, p. 216). Once again, history is used as an agent of myth, with the idea of "freedom for all" doing the heavy lifting. According to the video, this freedom, carried by the diversity emergent from immigration, is fully realized today, and only partially muddied in the past.

In this context, the images of multi-ethnic people, especially those of women, Native Americans, the handicapped (reduced to a mere symbol) are meant to represent diversity (Pena et al., 2018; Wu \& Ida, 2018). These images are "non-performative" (Ahmed, 2006). They do not do the action of diversity; caught up in myth, they substitute the semiotics of freedom to paper the glaring gaps concerning struggles for equality in the United States.

In short, the video neglects to mention that not all people in America enjoy the same freedoms; that racism, homophobia, and misogyny (to name a few) are still deeply embedded within American culture and institutions. Such erasure not only furthers the problematic American dream myth, it also opens up the space for what Das Gupta (2006) called "place taking" and "space making" politics. Place taking politics involve normative power dynamics, wherein immigrants take their place, so-to-speak, within a rights framework based on citizenship (Das Gupta, 2006). Once citizenship is attained, immigrants will start enjoying the rights and shouldering the responsibilities placed upon them by and for freedom (Das Gupta, 2006). The video, of course, hammers this conception, an idea that arguably works well if one is the "right kind" of immigrant.

Das Gupta (2006) advocated for a "theoretical intervention in rights talk," a space making politics that among other things considers rights based on those made most vulnerable by hegemonic systems of power (p. 19). If one were to take the video at face value, then there would be no need for a space making politics. Of course, the material reality on the ground in the U.S. departs greatly from the myth, necessitating a need for immigration reform of the kind suggested by Das Gupta (2006) in the quest for a transnational, mobile complex of rights for migrant individuals, and not just the place taking, document holding, test taking, gender and sexuality conforming immigrants. Furthermore, the "right kind of immigrant" is a moving target. For example, Mexicans have been rhetorically, politically, and socially welcomed in some periods of American history and brutally evicted in others (Flores, 2003).

A counter-analysis of the video might argue that less myth making would be counterproductive. At a political level, the United States wants to persuade people, including foreigners, that the U.S. does in fact perform freedom, that it always has (post-inoculation) and always will live up to its reputation as the defender of the free world. The approach taken in the video is arguably better than the Dutch project which perhaps takes nationalism to the level of micromanagement what with its gardening instructions.

It could also be argued that while a more confessional, realist tone in the U.S. video might be of use to immigrants, such a project would be impractical. Indeed, it would be exceedingly difficult to reach consensus around how to depict the debate around reproductive rights in the United States, for example. However, such an attempt to acknowledge struggles is important, and since the video stresses the role of debate in the formation and maintenance of the U.S. government, a little more contention in the video is in order. 


\section{Conclusion}

A Promise of Freedom: An Introduction to U.S. History and Civics for Immigrants (National Constitution Center, 2007) would be more aptly subtitled: An Introduction to U.S. Mythology. As demonstrated, the video deploys specific visual, aural, and narrative strategies to further an uncomplicated notion of American freedom, past and present. The U.S. video directly instructs immigrants applying for citizenship to do certain things, chief among them voting. This emphasis on electoral, establishment politics furthers a sense that place taking politics (Das Gupta, 2006), and individual (not collective) action, are the only avenues for change in America.

How do immigrants receive the video? Are there multiple readings, per Hall (1974), from the so-called target demographic? What is the level of cultural literacy on the part of the audience? Do the "space making" immigrants (Das Gupta, 2006), those most at risk, see problems in the rights-based framework of the video? Clearly, acculturation videos are remarkable and understudied sites of meaning making on a global scale.

Finally, the very definition of immigrant is a site of contestation. As more and more lives are increasingly characterized by relationships to technology, scholars must interrogate an increasingly complex world, crowded with a proliferation of things. Here, the popular phrases "digital immigrants" and "digital natives" are apt for consideration. Circulating in technocratic systems, "consumers are transformed into immigrants" (de Certeau, 1984, p. 40). In other words, by my reading, the digital is not a place to arrive at or to be from, no matter one's physical age. "The system in which they [immigrants] move about is too vast to be able to fix them in one place, but too constraining for them to be able to escape from it and go into exile elsewhere" (de Certeau, 1984, p. 40). In this environment, "we the people" mobilize tactics for freedom, hopefully realized globally and expressed locally. We are all immigrants striving for better lives, or so goes a different myth.

Disclosure statement. The author received no financial support for the research, authorship, and/or publication of this article.

\section{References}

Ahmed, S. (2006). The nonperformativity of antiracism. Meridians, 7(1), $104-126$.

Alvarez, P., \& Sands, G. (2019, July 20). Trump admin is revising the citizenship test. CNN. Retrieved July 27, 2019, from https:/www.cnn.com/2019/07/19/politics/citizenship-testrevision/index.html

Andrews, K. (2019). Book Review: Human Rights and Global Diversity: Basic Ethics in Action. Journal Of Curriculum Ttudies Research, 1(1), 71-74. https://doi.org/10.46303/jcsr.01.01.6

Anguiano, C. A. (2015). Dropping the 'I-word': A critical examination of contemporary immigration labels. In Hartelius (Ed.), Rhetorics of immigration: Identity, community and otherness (pp. 93-111). Penn State University Press.

Anonymous. (2009). Naar nederland. Retrieved Nov 1, 2012, from http://www.youtube.com/watch?v=6r61CXkq0HE

Aronczyk, M. (2019). Branding national identity in an unequal world. In F. Wherry, \& I. Woodward (Eds.), The Oxford handbook of consumption (pp. 439 - 457). Oxford University Press. 
Asante, G. A. (2019). \#RhetoricSoWhite and US centered: Reflections on challenges and opportunities. Quarterly Journal of Speech, 105(4), 484-488. https://doi.org/10.1080/00335630.2019.1669892

Banet-Weiser, S. (2007). What's your flava? Race and postfeminism in media culture. In Y. Tasker, $\&$ D. Negra (Eds.), Interrogating postfeminism: Gender and the politics of popular culture (pp. 201-226). Duke University Press.

Barthes, R. (1972). Mythologies (A. Lavers Trans.). Hill and Wang.

Barthes, R. (1977). Image, music, text (S. Heath Trans.). Hill and Wang

Benson, R. (2013). Shaping immigration news: A French-American comparison. Cambridge University Press.

Berray, M. (2019). A critical literary review of the Melting Pot and Salad Bowl Assimilation and integration theories. Journal of Ethnic and Cultural Studies, 6(1), 142151. http://dx.doi.org/10.29333/ejecs/217

Bittman, B.\& Russell, W. (2016). Civic Education in United States: A Multiple Regression of Civic Education Scores from the National Assessment of Educational Progress. Research in Social Sciences and Technology, 1(2). Retrieved from https://ressat.org/index.php/ressat/article/view/16

Bradford, A. C. (2019). "Another foothold in our fight against communism": Race, religion, and public relations in the Hungarian and Cuban refugee programs, 1956-1961. U.S. Catholic Historian, 37(3), 43-76. https://doi.org/10.1353/cht.2019.0017.

Brown, A. (2012). Trapped by narcissism: A disillusioned Dutch society. Macelester International, $30(7), 22-46$.

Chandler, D. (2017). Semiotics for beginners. Retrieved July 17, 2019, from http://visualmemory.co.uk/daniel/Documents/S4B/sem05.html

Chavez, L. R. (2013). The Latino threat: Constructing immigrants, citizens, and the nation (2nd ed.). Stanford University.

Chomsky, N. (2013, Aug. 17). Chomsky: The U.S. behaves nothing like a democracy. Salon. Retrieved Sept 1, 2013, from http://www.salon.com/2013/08/17/chomsky_the_u_s_behaves_nothing_like_a_democrac y/

Cowgill, D. A., \& Waring, S. M. (2017). Historical thinking: An evaluation of student and teacher ability to analyze sources. Journal of Social Studies Education Research, 8(1), 115-145.

Das Gupta, M. (2006). Unruly immigrants: Rights, activism, and transnational South Asian politics in the United States. Duke University Press.

de Certeau, M. (1984). The practice of everyday life (S. Rendall, Trans.). Berkeley: University of California Press.

Etzioni, A. (2007). Citizenship tests: A comparative, communitarian perspective. The Political Quarterly, 78(3), 353-363. https://doi.org/10.1111/j.1467-923X.2007.00864.X

Federal Office for Migration and Refugees-Germany. (2019). Pictures and videos. Retrieved July 13, 2019, from http://www.bamf.de/EN/Infothek/BilderVideos/bildervideos-node.html

Flores, L. (2003). Constructing rhetorical borders: Peons, illegal aliens, and competing narratives of immigration. Critical Studies in Media Communication, 20(4), 362-387. https://doi.org/10.1080/0739318032000142025

French Office of Immigration and Integration. (2019). Retrieved July 13, 2019, from http://www.ofii.fr/ 
Girardelli, D. (2004). Commodified identities: The myth of Italian food in the United States. Journal of Communication Inquiry, 28(4), 307-324. https://doi.org/10.1177/0196859904267337

Giroux, H. (2008). Against the terror of neoliberalism: Politics beyond the age of greed. Paradigm. Hall, S. (1974). Encoding and decoding in the television discourse. Centre for Cultural Studies, 506-517.

Hall, S. (2003). The whites of their eyes: Racist ideologies and the media. Sage Publications.

Helenic Republic Ministry of Interior. (2019). Asylum service. Retrieved July 13, 2019, from http://asylo.gov.gr/en/

Hoops, J. F. \& Braitman, K. (2018): The influence of immigration terminology on attribution and empathy. Critical Discourse Studies. https://doi.org/10.1080/17405904.2018.1535989

Howells, R., \& Negreiros, J. (2012). Visual culture. (2nd ed.). Polity Press.

Human Rights Watch. (2019). World report 2019: European Union-Greece. Retrieved July 13, 2019, from https://www.hrw.org/world-report/2019/country-chapters/europeanunion\#6b7186

Johnson, M. A. (2020). Communicating identity histories in ethnic museum public relations. In I. Somerville, L. Edwards, \& Ø. Ihlen (Eds.), Public relations, society and the generative power of history (pp. 127-142). Routledge.

Kenna, J., \& Russell III, W. (2018). The Culture and History of Standards-Based Educational Reform and Social Studies in America. Journal of Culture and Values in Education, 1(1), 26-49. Retrieved from http://cultureandvalues.org/index.php/JCV/article/view/2

Kusumastuti, F. (2019). Polysemy in and of the Science Fiction Film Arrival (2016). Research in Social Sciences and Technology, 4(1), 73-91. https://doi.org/10.46303/ressat.04.01.4

Manuel, O. (2019, July 24). No shower for 23 days. Dallas Morning News. Retrieved July 27, 2019, from https://www.dallasnews.com/news/immigration/2019/07/24/no-shower-23days-us-citizen-held-deportation-shares-like-immigrant

Mason, L. (2019). Dewey and Political Communication in the Age of Mediation. Journal of Culture and Values in Education, 2(3), 94-102. https://doi.org/10.46303/jcve.03.02.6

McRobbie, A. (2004). Post-feminism and popular culture. Feminist Media Studies. 4(3), 255-26. https://doi.org/10.1080/1468077042000309937

Meier, L. (2019). Questioning the Problematic Nature of School Culture in Elementary Teacher Education. Journal of Culture and Values in Education, 2(1), 34-44. Retrieved from http://cultureandvalues.org/index.php/JCV/article/view/30

Moore, J. (2018). Don't Shut Up: Why Teachers Must Defend the First Amendment in Secondary Schools. Journal of Culture and Values in Education, 1(2), 23-41. Retrieved from http://cultureandvalues.org/index.php/JCV/article/view/10

National Constitution Center. (2007). A promise of freedom: An introduction to U.S. history and civics for immigrants. Retrieved Nov 1, 2012, from http://www.uscis.gov/portal/site/uscis/menuitem.acfc8bb2d633f506e34f4a10526e0aa0/?v

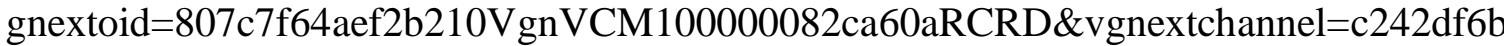
dd42a210VgnVCM100000b92ca60aRCRD

Peña, C., Jones, L., Orange, A., Simieou, F., \& Márquez, J. (2018). Academic success and resiliency factors: A case study of unaccompanied immigrant children. American Journal of Qualitative Research, 2(1), 161-181.

Quinsaat, S. (2014). Competing news frames and hegemonic discourses in the construction of contemporary immigration and immigrants in the United States. Mass Communication and Society, 17, 573-596. https://doi.org/10.1080/15205436.2013.816742

Saussure, F. (1974 (1906-1911)). A course in general linguistics. London: Fontana. 
Sieff, K. (2018, August 29). U.S. is denying passports to Americans along the border, throwing their citizenship into question. The Washington Post. https://www.washingtonpost.com

Wu, B. \& Ida, K., A. (2018). Ethnic Diversity, Religion, and Opinions toward Legalizing Abortion: The Case of Asian Americans. Journal of Ethnic and Cultural Studies, 5(1), 94-109.

\section{Notes on Contributors}

Camille Reyes, $\mathrm{PhD}$, is Assistant Professor of Public Relations at Trinity University in San Antonio, Texas. Her work has appeared in journals such as Public Relations Inquiry and Communication, Culture, and Critique. 